\title{
EKSISTENSI PROGRAM PENDAFTARAN TANAH SISTEMATIS LENGKAP (PTSL) DALAM MENCEGAH TERBITNYA SERTIPIKAT GANDA DI KANTOR PERTANAHAN KOTA DENPASAR
}

\author{
Oleh : \\ Made Emy Andayani Citra \\ I Made Sudirga \\ Fakultas Hukum Universitas Mahasaraswati Denpasar \\ emyandayanifh@gmail.com, sudix294@yahoo.com
}

\begin{abstract}
Land is a very important thing for human survival, this is important because land is usually used to build buildings on it such as buildings, offices, housing and others. Land is important because it is used as a source of livelihood, which is land used as agriculture, animal husbandry, plantations and others. As the population grows, the need for land for residential needs and development needs is increasing, while the area of land is relatively fixed. Although land has many benefits, land can also trigger disputes between people and others, because every human being wants to control the land owned by someone else due to the natural resources contained therein, or because of the value that can be generated from the land.With the increasing number of disputes that occur due to the land, there needs to be a breakthrough in handling it, so that with the issuance of the Systematic Complete Land Registration (PTSL) program it is very feasible to do to at least minimize the land dispute.
\end{abstract}

Keywords: Land, Land Dispute, PTSL

\begin{abstract}
Abstrak
Tanah merupakan suatu hal yang sangat penting bagi kelangsungan hidup manusia, hal ini menjadi penting karena tanah biasanya digunakan untuk mendirikan bangunan diatasnya seperti gedung, kantor, perumahan dan lainnya. Tanah menjadi penting karena digunakan sebagai sumber mata pencaharian, yang dimana tanah dijadikan pertanian, peternakan, perkebunan dan lainnya. Seiring dengan pertambahan jumlah penduduk, kebutuhan akan tanah untuk keperluan rumah tempat tinggal dan keperluan pembangunan semakin meningkat, sedangkan luas tanah adalah relatif tetap. Meskipun tanah memiliki banyak manfaat, tetapi tanah pun dapat memicu persengketaan antar manusia dengan yang lainnya, karena setiap manusia ingin menguasai tanah milik orang lain dikarenakan sumber-sumber daya alam yang terkandung di dalamnya, ataupun dikarenakan nilai yang dapat dihasilkan dari tanah tersebut. Dengan makin banyaknya sengketa yang terjadi akibat tanah tersebut, perlu adanya suatu terobosan dalam menangani hal tersebut, sehingga dengan dikeluarkannya program Pendaftaran Tanah Sistematis Lengkap (PTSL) sangat layak untuk dilakukan untuk paling tidak meminimalisir sengketa tanah tersebut.
\end{abstract}

Kata Kunci : Tanah, Sengketa Tanah, PTSL 


\section{A. PENDAHULUAN}

\section{Latar Belakang}

Tanah mempunyai arti penting dalam kehidupan manusia sebagai tempat memproduksi ataupun sebagai pemukiman. Tanah merupakan obyek investasi dan mengakibatkan nilai harga tanah akan semakin menjulang tinggi. Halhal tersebut sering mengakibatkan terjadinya sengketa, konflik dan perkara pertanahan lainnya. ${ }^{1}$ Pentingnya peranan tanah bagi kelangsungan hidup manusia maka perlu dilakukannya pendaftaran tanah, sehingga dalam hal ini tanah yang telah di daftarkan dapat memberikan jaminan kepastian hukum bagi pemilik tanah dan tidak akan menimbulkan konflik atau sengketa bagi pemiliknya di dalam lingkungan masyarakat untuk kedepannya.

Pendaftaran tanah adalah tugas Pemerintah Republik Indonesia sebagaimana diamanatkan oleh Undang-Undang Republik Indonesia

${ }^{1}$ Bronto Susanto, Kepastian Hukum Sertipikat Hak Atas Tanah Berdasarkan Peraturan Pemerintah Nomor 42 tahun 1977, Fakultas Hukum Untag Surabaya, Vol.10, No. 20 Agustus 2014, h.76
Nomor 5 tahun 1960 tentang Peraturan Dasar Pokok- Pokok Agraria Pasal 19 ayat (1) sebagai dasar pelaksanaan pendaftaran tanah di Indonesia yang menyebutkan untuk menjamin kepastian hukum oleh pemerintah diadakan pendaftaran tanah diseluruh wilayah Republik Indonesia menurut ketentuan-ketentuan yang diatur dengan Peraturan Pemerintah. ${ }^{2}$

Proses pendaftaran tanah dilakukan melalui tiga tahap kegiatan yaitu kegiatan pengumpulan dan pengolahan data fisik, pengumpulan dan pengolahan data yuridis dan penerbitan dokumen tanda bukti hak. Dalam kegiatan pengumpulan dan pengolahan data yuridis yaitu dengan meneliti alat- alat bukti kepemilikan tanah. $^{3} \quad$ Pendaftaran tanah secara sistematis lengkap diselenggarakan atas prakasapemerintah berdasarkan suatu rencana kerja jangka panjang dan tahunan serta dilaksanakan di wilayah- wilayah yang ditetapkan

2 Yamin Lubis dan Rahim Lubis, 2008, Hukum Pendaftaran Tanah, Mandar Maju, Bandung, h.81

${ }^{3}$ Pandu Eka Pramuditya, Pelaksanaan Pendaftaran Hak Milik Atas Tanah Negara di Surakarta, Fakultas Hukum Universitas Negeri Sebelas Maret Surakarta, Vol.III No.2, Juli 2016, h.107 
oleh Menteri Negara Agraria atau Kepala Badan Pertanahan Nasional. ${ }^{4}$

Sistem Pendaftaran Sistematis Lengkap (PTSL) ini telah diatur oleh Pemerintah melalui Peraturan Menteri Agraria dan Tata Ruang/ Kepala Badan Pertanahan Nasional Republik Indonesia Nomor 6 Tahun 2018 tentang Pendaftaran Tanah Sistematis Lengkap sebagai pedoman dalam melaksanakan pendaftaran tanah sistematis lengkap bidang yuridis dan sebagai standarisasi dan keseragaman dalam melaksanakan pendaftaran tanah sistematis lengkap secara yuridis.Negara wajib memberikan kepastian hukum dalam bidang pertanahan dengan melakukan pendaftaran tanah, sebagaimana dimanatkan UndangUndang Nomor 5 tahun 1960 tentang Peraturan Dasar PokokPokok Agraria Pasal 19 ayat (1) yaitu: "Untuk menjamin kepastian hukum oleh Pemerintah diadakan pendaftaran tanah di seluruh wilayah Republik Indonesia menurut

\begin{tabular}{l}
\hline 4 Tongam Nadeak, 2018, \\
Implementasi Kebijakan Percepatan \\
Pelaksanaan Pendaftaran Tanah Sistematis \\
Lengkap (PTSL) di Badan Pertanahan \\
Nasional Kota Medan ,Universitas Sumatera \\
Utara,h.15
\end{tabular}

ketentuanketentuan yang diatur dengan Peraturan Pemerintah”. Sebagai tindak lanjut Pemerintah mengundangkan Peraturan Pemerintah Nomor 24 tahun 1997 tentang Pendaftaran Tanah. Hasil akhir dari pendaftaran tanah adalah dengan diterbitkannya sertipikat hak atas tanah sebagaimama diatur dalam Peraturan Pemerintah Nomor 24 tahun 1997 tentang Pendaftaran Tanah Pasal 4 ayat (1).

Sertipikat hak atas tanah befungsi untuk memberikan kepastian dan perlindungan hukum terhadap pemegang sertifikat tersebut. Pendaftaran tanah yang semestinya memberikan kepastian hukum, justru terkadang memberikan ketidakpastian hukum, semisal karena tumpang tindihnya keterangan tanah akibat kesalahan dan ketidakcermatan pendaftaran. Salah satu contoh adalah kasus Sertifikat ganda yang juga biasa disebut Sertifikat Tumpang Tindih8. Akibat dari terbitnya sertipikat ganda tersebut menimbulkan sengketa perdata antar para pihak. Dalam menyelesaikan sengketa tersebut dapat ditempuh melalui dua cara 
yaitu cara penyelesaian melalui instansi Badan Pertanahan Nasional atau yang biasa disebut dengan cara musyawarah serta cara yang kedua yaitu melalui jalur peradilan. Sengketa sertipikat ganda merupakan bentuk kesalahan administratif oleh pihak Badan Pertanahan Nasional dalam hal melakukan pendataan atau pendaftaran tanah pada satu obyek tanah. Bentuknya bisa dikarenakan faktor kelalaian, atau terdapat oknum yang memalsukan data. Sebab dari adanya sertifikat ganda telah menimbulkan kerugian dari pihak yang seharusnya mendapatkan kepastian hukum dan perlindungan. Tanah memiliki nilai ekonomis yang cukup tinggi dan merupakan simbol eksistensi dan status sosial di tengah masyarakat. ${ }^{5}$

Berdasarkan latar belakang diatas penulis terdorong melakukan penelitian dengan judul “EKSISTENSI PROGRAM PENDAFTARAN TANAH SISTEMATIS LENGKAP (PTSL) DI KANTOR PERTANAHAN KOTA DENPASAR”

5 Bernhard Limbong, 2012, Konflik Pertanahan, Margareta Pustaka, Jakarta, h.2
Berdasarkan latar belakang diatas maka rumusan masalah dalam penelitian ini adalah :

1. Bagaimana mekanisme pelaksanaan program Pendaftaran Tanah Sistematis Lengkap (PTSL) di Kantor Pertanahan Kota Denpasar?

2. Bagaimana Eksistensi Program Pendaftaran Tanah Sistematis Lengkap dalam Mencegah Terbitnya Sertipikat Ganda di Kantor Pertanahan Kota Denpasar?

\section{Metode Penelitian}

Penelitian ini menggunakan jenis penelitian hukum empiris. Penelitian hukum empiris dapat dikatakan juga sebagai suatu metode penelitian hukum yang berfungsi untuk melihat hukum dalam artian nyata serta meneliti bagaimana bekerjanya hukum disuatu lingkungan masyarakat. ${ }^{6}$

\footnotetext{
6 Bambang Sunggono,2012, Metode Penelitian Hukum, Raja Grafindo, Jakarta h. 42
} 
B. PEMBAHASAN

1. Mekanisme Pelaksanaan Program Pendaftaran Tanah Sistematis Lengkap (PTSL) di Kantor Pertanahan Kota Denpasar

Secara umum mekanisme pelaksanaan pendaftaran tanah sistematis lengkap diatur dalam Pasal 4 ayat (4) Peraturan Menteri Agraria dan Tata Ruang/Kepala Badan Pertanahan Nasional Republik Indonesia Nomor 6 Tahun 2018 tentang Pendaftaran Tanah

Sistematis Lengkap yang meliputi :

a. Perencanaan;

Penyelenggaraan pendaftaran tanah sistematis lengkap dapat dilaksanakan melalui kegiatan pendaftaran tanah sistematis lengkap, atau gabungan dari kegiatan pendaftaran tanah sistematis lengkap dengan program dan/atau kegiatan lain seperti Program Sertipikasi Lintas Sektor dan Program Sertipikasi massal swadaya masyarakat serta program atau kegiatan sertipikasi massal redistribusi tanah objek landreform, konsolidasi tanah, dan transmigrasi.

b. Penetapan lokasi;

Kepala Kantor Pertanahan menetapkan lokasi kegiatan Pendaftaran Tanah Sistematis Lengkap di wilayah kerjanya. Penetapan Lokasi dapat dilakukan dalam satu wilayah desa/kelurahan atau secara bertahap bagian demi bagian dalam satu hamparan

c. Persiapan;

Kepala Kantor Pertanahan melakukan persiapan pelaksanaan kegiatan Pendaftaran Tanah Sistematis Lengkap.

d. Pembentukan dan penetapan panitia ajudikasi PTSL dan satuan tugas;

Kepala Kantor Pertanahan membentuk dan menetapkan Panitia Ajudikasi Pendaftaran Tanah Sistematis Lengkap

e. Penyuluhan;

Penyuluhan akan dijadwalkan terlebih dahulu dan dilaksanakan oleh petugas badan pertanahan nasional beserta panitia ajudikasi. 
Penyuluhan ini dilakukan kepada seluruh masyarakat peserta program pendaftaran tanah sistematis lengkap baik yang sudah memiliki sertipikat atau belum memiliki sertipikat

f. Pengumpulan data fisik dan pengumpulan data yuridis;

Pengumpulan Data Fisik dilaksanakan melalui kegiatan pengukuran dan pemetaan bidang tanah. Pengukuran dan pemetaan bidang tanah dilakukan dengan menggunakan teknologi survei dan pemetaan yang telah disediakan. Sedangkan Pengumpulan data yuridis meliputi pengumpulan alat bukti mengenai kepemilikan atau penguasaan tanah, baik bukti tertulis, keterangan saksi atau pernyataan yang bersangkutan.

g. Penelitian data yuridis untuk pembuktian hak;

Panitia ajudikasi pendaftaran tanah sistematis lengkap melakukan penelitian data yuridis untuk keperluan pembuktian hak. Dalam hal bukti kepemilikan tanah masyarakat tidak lengkap atau tidak ada sama sekali maka dapat dilengkapi dan dibuktikan dengan surat pernyataan tertulis tentang pemilikan atau penguasaan fisik bidang tanah dengan itikad baik oleh yang bersangkutan.

h. Pengumuman data fisik dan data yuridis serta pengesahannya;

Untuk memenuhi asas publisitas dalam pembuktian pemilikan tanah, data yuridis dan data fisik bidang tanah dan peta bidang-bidang tanah diumumkan dengan menggunakan formulir Pengumuman Data Fisik dan Data Yuridis selama empat belas hari kalender di Kantor Panitia Ajudikasi pendaftaran tanah sistematis lengkap dan Kantor Kepala Desa/Kelurahan. Setelah masa pengumuman berakhir, data fisik dan data yuridis disahkan oleh Panitia Ajudikasi Pendaftaran Tanah Sistemaris 
Lengkap yang dibuat dalam bentuk Berita Acara Pengesahan Pengumuman Data Fisik dan Data Yuridis

i. Penegasan konversi, pengakuan hak dan pemberian hak;

Ketua Panitia Ajudikasi

Pendaftaran Tanah Sistematis Lengkap menegaskan konversi menjadi Hak Milik atas nama pemegang hak yang terakhir, untuk bidang tanah yang alat bukti tertulisnya lengkap dan yang alat bukti tertulisnya tidak lengkap tetapi ada keterangan saksi maupun pernyataan yang bersangkutan dan menetapkan pengakuan atau penegasan sebagai Hak Milik, untuk bidang tanah yang alat bukti kepemilikannya tidak ada tetapi telah dibuktikan dengan kenyataan penguasaan fisiknya selama 20 (dua puluh) tahun secara terus menerus termasuk pendahulu-pendahulunya serta mengusulkan keputusan pemberian hak, untuk bidang tanah yang merupakan tanah Negara dengan mengusulkan secara kolektif kepada Kepala

Kantor Pertanahan dengan menggunakan Daftar Usulan Pemberian Hak Milik/Guna Bangunan/Pakai .

j. Pembukuan hak;

Pembukuan hak, pembatasanpembatasan yang bersangkutan dengan hak tersebut termasuk pembatasan dalam pemindahan hak, pembatasan dalam penggunaan tanah menyangkut garis sempadan pantai, sungai dan lain-lain, juga dicatat pembatasan penggunaan tanah hak dalam kawasan lindung. Penandatanganan Buku Tanah dilakukan oleh Ketua Panitia Ajudikasi atas nama Kepala Kantor Pertanahan. Bentuk, isi dan tata cara pengisian buku tanah dilakukan sesuai dengan ketentuan peraturan perundang-undangan.

k. penerbitan sertipikat hak atas tanah;

Hak Milik, Hak Guna Bangunan, Hak Pakai dan wakaf yang sudah didaftar dalam buku tanah dan memenuhi syarat untuk 
diberikan tanda bukti haknya akan diterbitkan sertipikat hak atas tanah. Penerbitan sertipikat oleh kementrian agraria tata ruang atau badan pertanahan nasional yang menjadi bukti otentik seseorang atas kepemilikan tanah miliknya

1. Pendokumentasian dan penyerahan hasil kegiatan Panitia Ajudikasi Pendaftaran Tanah Sistematis Lengkap melakukan pengumpulan, pengelompokan, pengolahan, dan penyimpanan data Pendaftaran Tanah Sistematis Lengkap. Ketua Panitia Ajudikasi pendaftaran tanah sistematis lengkap menyerahkan hasil pelaksanaan kegiatan pendaftaran tanah sistematis lengkap kepada Kepala Kantor Pertanahan pada akhir kegiatan pendaftaran tanah sistematis lengkap dan disertai dengan data pendaftaran tanah sistematis lengkap. Penyerahan hasil pelaksanaan kegiatan pendaftaran tanah sistematis lengkap dibuat dalam bentuk

Berita Acara Serah Terima berkas dan warkah hasil kegiatan pendaftaran tanah sistematis lengkap yang ditandatangani oleh Ketua Panitia Ajudikasi pendaftaran tanah sistematis lengkap dan Kepala Kantor Pertanahan.

m. Pelaporan Pelaporan pelaksanaan kegiatan pendaftaran tanah sistematis lengkap dilaksanakan pada saat terjadi permasalahan dalam pelaksanaan kegiatan pendaftaran tanah sistematis lengkap dan pendaftaran tanah sistematis lengkap selesai dilaksanakan

Pada Program Pendaftaran Tanah dalam mekanisme pelaksanaannya dilaksankan tahap Plotting peta yang dimana pemohon wajib menunjukkan lokasi tanahnya di peta monitor. Jika lokasi yang ditunjuk dalam peta ternyata sudah ada plotingan bidang maka akan dicek kembali terhadap kepemilikan dalam obyek tersebut dan pemohon dipersilahkan untuk melakukan 
klarifikasi apabila dalam obyek tersebut belum ada plottingan maka sertipikat baru bisa didaftarkan. Upaya Plotting ini menggunakan teknologi GPS (Global Positioning System) untuk masuk ke dalam peta pendaftaran. Hasil plotting akan menunjukkan apakah benar di lokasi tersebut terdapat lahan kepemilikan sesuai keterangan di sertifikat. Apabila benar, hasilnya akan menunjukkan sertifikat tersebut asli. Artinya, baik data pendaftaran dan lokasi tanah bersifat valid. Sebaliknya, jika tidak ditemukan tanah pada lokasi, maka sertifikat dinilai tidak valid. Jika terbukti sudah ada sertipikat terdaftar pada lokasi tersebut maka permohonan akan ditolak sehingga tidak ada potensi sertipikat ganda.

Berdasarkan wawancara dengan Bapak I Gde Witha Arsana, S. SiT selaku Kepala Seksi Insfrastruktur Pertanahan di Kantor Pertanahan Kota Denpasar Dalam hal melaksanakan Plotting ini Kantor Pertanahan Nasional menemukan beberapa kendala yaitu :

1. Adanya Overlapping penuh antara beberapa sertipikat, overlapping sebagian dilokasi yang sama, overlapping sebagian dengan sertipikat penyanding.

2. Bentuk tanah pada sertipikat berbeda dengan dilapangan.

3. Sertipikat tidak bisa diplotting karena tidak diketahui lokasi letak tanahnya

4. Sertipikat tidak bisa di plotting karena pada lokasi yang sama sudah terbit sertipikat baru tetapi sertipikat lama masih aktif atau belum dimatikan secara administrasi.

Melihat berbagai kendala tersebut Kantor Pertanahan Kota Denpasar melakukan beberapa cara dalam mengatasi kendala tersebut yaitu :

1. Untuk sertipikat yang overlapping para pihak harus member keterangan mengenai penunjukan batas kepemilikan hak tanah .

2. Pada bentuk tanah yang berbeda para pemilik tanah wajib mengganti sertipikat hak atas tanah tersebut berdasarkan kenyataan dilapangan 
3. Pada sertipikat yang tidak diketahui lokasi letak tanahnya, pihak Kantor Pertanahan Kota Denpasar melakukan sosialisasi di desa serta dibantu oleh kepala desa untuk mencari letak tanah tersebut dan apabila tanah tersebut memang tidak adadisini pihak Kantor Pertanahan Kota Denpasar akan meneliiti warkahnya terlebih dahulu jika memang sertipikat tersebut harus dicabut atau dimatikan maka akan dimatikan secara sistem.

4. Pada sertipikat yang tidak bisa diplotting karena pada lokasi yang sama sudah terbit sertipikat baru tetapi sertipikat lama masih aktif pihak Kantor Pertanahan Kota Denpasar akan melakukan sosialisasi di desa atau kelurahan yang dibantu oleh kepala desa untuk mendapatkan informasi mengenai kepemilikan hak atas tanah yang sebenarnya

\section{Eksistensi}

Pendaftaran

Sistematis Lengkap (PTSL)

Dalam Mencegah Terbitnya Sertipikat Ganda Di Kantor Pertanahan Kota Denpasar

Berdasarkan wawancara dengan Bapak I Ketut Sutrisna selaku Kepala Kepala Sub Seksi Penetapan Hak dan Pemberdayaan Masyarakat mengatakan babhwa pendaftaran tanah untuk pertama kali dilaksanakan melalui pendaftaran tanah secara sistematik dan pendaftaran tanah secara sporadik. Pada program nasional agraria pendaftaran tanah yang digunakan adalah pendaftaran tanah secara sporadik dimana dilaksanakan atas permintaan pihak yang berkepentingan. Pada program pendaftaran tanah sistematis lengkap yang digunakan adalah pendaftaran tanah secara sistematis didasarkan pada suatu rencana kerja dan dilaksanakan di wilayah-wilayah yang ditetapkan oleh Menteri. Pendaftaran tanah sistematis lengkap yang mendaftarkan tanah tersebut adalah pemerintah dimana dalam suatu wilayah terentu secara serentak 
semua tanah dibuatkan sertipikat hak atas tanahnya.

Pendaftaran tanah di Indonesia termasuk juga di Kantor Pertanahan Kota Denpasar sebelum 2017 dikenal dengan nama Program Nasional Agraria (Prona). Mengenai Program Nasional Agraria (Prona) diatur dalam Peraturan Menteri Agraria dan Tata Ruang/Kepala Badan Pertanahan Nasional No. 4 Tahun 2015 tentang Program Nasional Agraria. Berhubungan dengan permasalahan pengurusan tanah yang makin meningkat, menuntut masyarakat untuk memahami tujuan dari melakukan pendaftaran tanah. Pandangan masyarakat untuk mengurus dan mendaftarkan tanah sangat memakan waktu yang lama dan kurangnya pengetahuan masyarakat menganai kelebihan dari pendaftaran tanah, membuat mereka enggan untuk mengurus pendaftaran tanah. Untuk terciptanya tertib hukum pertanahan, Pemerintah dalam hal ini mengeluarkan program terobosan terbaru yaitu Pendaftaran Tanah Sistematis Lengkap. Program ini dibentuk berdasarkan Peraturan Menteri Agraria dan Tata
Ruang/Kepala Badan Pertanahan Nasional Republik Indonesia Nomor 6 Tahun 2018 tentang Pendaftaran Tanah Sistematis Lengkap.

$$
\text { Program Pendaftaran Tanah }
$$
Sistematis Lengkap (PTSL) adalah kegiatan pendaftaran tanah untuk pertama kali yang dilakukan secara serentak yang meliputi semua obyek pendaftaran tanah yang belum di daftar dalam satu wilayah desa atau kelurahan atau nama lainnya yang setingkat dengan itu dalam rangka memberikan jaminan kepastian hukum dan perlindungan hukum hak atas tanah rakyat secara adil dan merata, serta mendorong pertumbuhan ekonomi negara pada umumnya dan ekonomi rakyat pada khususnya. Pendaftaran tanah secara sistematis lengkap diselenggarakan atas prakasa pemerintah berdasarkan suatu rencana kerja jangka panjang dan tahunan serta dilaksanakan di wilayah- wilayah yang ditetapkan oleh Menteri Negara Agraria atau Kepala Badan Pertanahan Nasional. Sistem Pendaftaran Sistematis Lengkap (PTSL) ini telah diatur oleh Pemerintah melalui Peraturan Menteri Agraria dan Tata Ruang/ 
Kepala Badan Pertanahan Nasional Republik Indonesia Nomor 6 Tahun 2018 tentang Pendaftaran Tanah Sistematis Lengkap sebagai pedoman dalam melaksanakan pendaftaran tanah sistematis lengkap bidang yuridis dan sebagai standarisasi dan keseragaman dalam melaksanakan pendaftaran tanah sistematis lengkap secara yuridis.

Berdasarkan wawancara dengan Bapak I Gde Witha Arsana, S.Sit selaku Kepala Seksi Infrastruktur Pertanahan di Kantor Pertanahan Kota Denpasar melihat banyaknya terjadi sengketa pertanahan contohnya sengketa sertipikat ganda yang terdapat pada pendaftaran tanah pada umumnya. Sekarang Pada Program Pendaftaran Tanah Sistematis Lengkap (PTSL) ada beberapa upaya pencegahan yang dilakukan agar tidak terjadinya kasus sertipikat ganda serupa yaitu :

1. Melakukan program komputerisasi peta pendaftaran tanah sehingga dari program tersebut dapat diketahui bidang-bidang tanah yang sudah bersertipikat.
2. Pada saat pemohon melakukan pendaftaran harus melewati tahap Plotting yang dimana pemohon wajib menunjukkan lokasi tanahnya di peta monitor. Jika lokasi yang ditunjuk dalam peta ternyata sudah ada plotingan bidang maka akan dicek kembali terhadap kepemilikan dalam obyek tersebut dan pemohon dipersilahkan untuk melakukan klarifikasi apabila dalam obyek tersebut belum ada plottingan maka sertipikat baru bisa didaftarkan. Upaya Plotting ini menggunakan teknologi GPS (Global Positioning System) untuk masuk ke dalam peta pendaftaran. Hasil plottingakan menunjukkan apakah benar di lokasi tersebut terdapat lahan kepemilikan sesuai keterangan di sertifikat. Apabila benar, hasilnya akan menunjukkan sertifikat tersebut asli. Artinya, baik data pendaftaran dan lokasi tanah bersifat valid. Sebaliknya, jika tidak ditemukan tanah pada lokasi, maka sertifikat dinilai tidak 
valid. Jika terbukti sudah ada sertipikat terdaftar pada lokasi tersebut maka permohonan akan ditolak sehingga tidak ada potensi sertipikat ganda.

3. Dengan mengumpulkan data sertipikat yang sudah terdaftar. Dalam hal ini Kantor Pertanahan memulai dengan mengumpulkan data- data yang masuk kedalam kluster 4 yang sudah bersertipikat tetapi belum lengkap kemudian sertipikat- sertipikat itu dikumpulkan dan dilakukan plotting terlebih dahulu. Dengan melakukan hal ini akan memudahkan pihak Kantor Pertanahan untuk melakukan pendaftaran tanah sehingga tidak terjadinya sertipikat ganda dalam program ini.

4. Melalui penertiban proses pendaftaran tanah. Salah satunya yaitu yang menjadi penyebab terjadinya sertipikat ganda adalah masalah penunjukan batas. Pada saat penunjukan batas sebisa mungkin penunjukan batas dilakukan oleh pihak yang bersangkutan dengan menyertakan para pihak yang tanahnya berbatasan dengan tanah obyek pengukuran. Pada saat proses pengumpulan dan penelitian data yuridis dan data fisik bidang tanah harus benarbenar diteliti kebenarannya terutama mengenai riwayat tanahnya. Sehingga tidak terjadi kesalahan dalam hal data fisik dan data yuridis tanah

5. Melalui penertiban administrasi yang berkaitan dengan tanah di desa Selain Kantor Pertanahan dalam hal ini desa sangat berpengaruh dalam proses pendaftaran tanah. Karena informasi tentang tanah banyak didapat dari desa salah satunya tanahtanah yang belum bersertipikat. Bagi tanah yang belum bersertipikat maka informasi kepemilikan tanah harus benarbenar akurat sehingga tidak terjadi tumpang tindih kepemilikan tanah.

6. Melalui program Pengadaan Peta Pendaftaran Tanah yang 


dilakukan oleh Kantor
Pertanahan. Untuk mencegah
terjadinya Sertipikat ganda hal
pertama yang harus dilakukan
adalah harus mengoptimalkan
administrasi pertanahan dan
pembuatan peta pendaftaran
tanah. Dengan adanya peta
pendaftaran tanah dan
administrasi pertanahan yang
baik kesalahan letak dan batas
dapat diketahui sedini
mungkin,hal itu dikarenakan
guna peta pendaftaran tanah
adalah untuk menyampaikan
bidang tanah dalam satu
wilayah cakupan yang mana
sertipikat tanahnya sudah
terbit. Sehingga jika ada
indikasi terhadap terjadinya
sertipikat ganda dapat segera
dilakukan pembatalan sedini
mungkin.

\section{PENUTUP}

1. Mekanisme pelaksanaan program Pendaftaran Tanah Sistematis Lengkap di Kantor Pertanahan l Kota Denpasar sudah sesuai dengan ketentuan Peraturan Menteri Agraria dan
Tata Ruang/Kepala Badan Pertanahan Nasional Republik Indonesia Nomor 6 Tahun 2018 tentang Pendaftaran Tanah Sistematis Lengkap Pasal 4 ayat (4) meliputi persiapan, penyuluhan, Pengumpulan data fisik yang meliputi penetapan batas bidang tanah, pengukuran, pemetaan bidang tanah, Pengumpulan data yuridis berupa identitas pemohon, Pemeriksaan tanah, Pengumuman dan penetapan hak, Pembukuan Hak, Penerbitan dan penyerahan sertipikat.

2. Eksistensi Program Pendaftaran Tanah Sistematis Lengkap dalam mencegah terbitnya sertipikat ganda di Kantor Pertanahan Kota Denpasar yaitu program ini merupakan salah satu program yang diciptakan untuk mengurangi sengketa- sengketa pertanahan seperti sengketa sertipikat ganda. Pada kawasan Kota Denpasar peran Program Pendaftaran Tanah Sistematis 


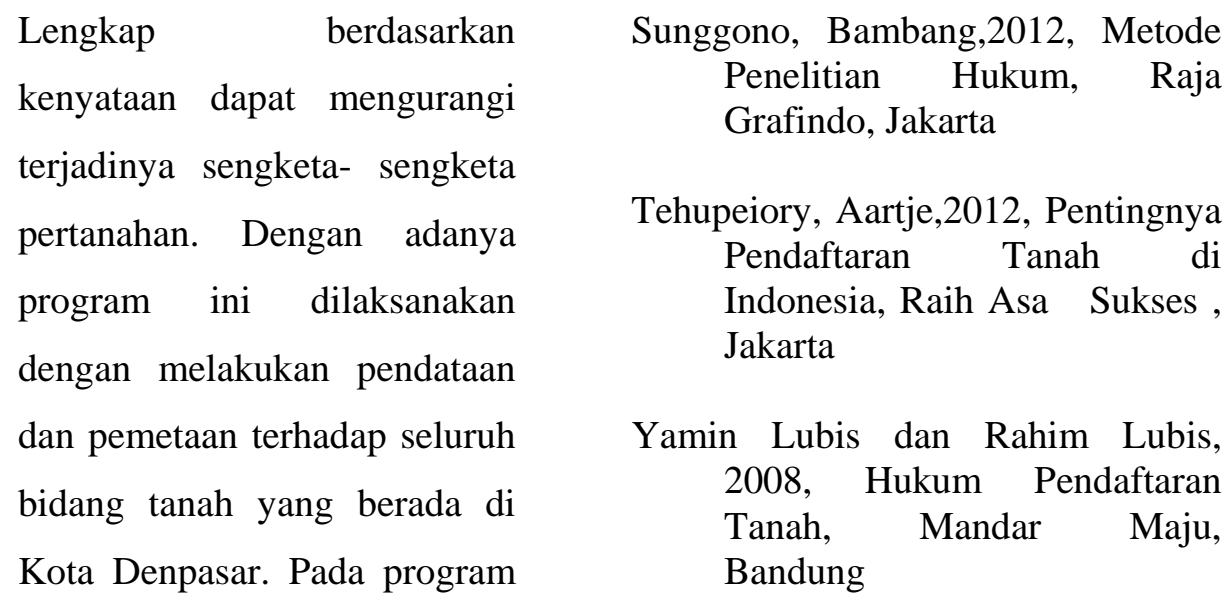

ini pihak kantor pertanahan kota denpasar dapat mencegah terjadinya masalah pertanahan dikemudian hari dan mendeteksi lebih awal masalah yang akan terjadi karena semua bidang tanah sudah terdaftar dan sudah terpetakan dan jika suatu saat kedepan adanya oknum yang mempunyai itikad tidak baik ingin mencoba membuat sertipikat pada bidang tanah yang sudah terpetakan akan terlihat bahwa bidang tanah tersebut sudah terdaftar hak atas tanahnya.

\section{DAFTAR PUSTAKA}

\section{BUKU}

Limbong,Bernhard, 2012, Konflik Pertanahan, Margareta Pustaka, Jakarta

\section{JURNAL}

Nadeak, Tongam, 2018, Implementasi Kebijakan Percepatan Pelaksanaan Pendaftaran Tanah Sistematis Lengkap (PTSL) di Badan Pertanahan Nasional Kota Medan ,Universitas Sumatera Utara

Pramuditya, Pandu Eka, 2016, "Pelaksanaan Pendaftaran Hak Milik Atas TanahNegara di Surakarta”, , Vol.III No.2, Fakultas Hukum Universitas Negeri Sebelas Maret Surakarta

Susanto, Bronto,2014, “Kepastian Hukum Sertipikat Hak Atas Tanah Berdasarkan Peraturan Pemerintah Nomor 42 tahun 1977”, Vol.10, No. 20 Fakultas Hukum Untag Surabaya 